International Journal of Public Finance
E-ISSN: $2548-0499 \quad$ DOI: $10.30927 /$ ijpf.327835
Vol./Cilt: 2 | Issue/Sayı: 1 | (2017), pp. $63-80$
journal homepage: http://dergipark.gov.tr/ijpf

\title{
Enhancing the Shariah Governance Framework for Malaysian IFIs through Effective Management Strategies
}

\author{
Hafiza HARUN $^{1} \quad$ Nurdianawati IRWANI ABDULLAH $^{2}$
}

\begin{tabular}{l} 
ARTICLE INFO \\
\hline Received: 11.07 .2017 \\
Received in revised \\
form: 26.08 .2017 \\
Accepted: 28.08 .2017 \\
Available online: \\
05.09.2017 \\
\hline JEL classification: \\
L2, O16 \\
\hline Keywords: \\
Shariah Governance \\
Framework (SGF), \\
Effective Management, \\
Islamic Financial \\
Institutions (IFIs) \\
\hline
\end{tabular}

\begin{abstract}
A B S T R A C T
This research paper explores the practical adoption which could be applied to the theoretical analysis and viable recommendation for further enhancement of the Shariah Governance Framework by all management teams in the Malaysian Islamic Financial Institutions. In complementing this study, a set of questionnaires is distributed to some selected group of staff in a Takaful Operator in Malaysia to gauge their understanding of the subject matter.

The effective and efficient organization needs to be embedded with a strong rapport between top management and another level of subordinates. This synergy simultaneously builds a robust governance for the organization, especially in Islamic finance area.
\end{abstract}

\section{Introduction}

The Shariah Governance Framework (SGF) in Malaysia has approached its fifth year of implementation by Malaysian Islamic Financial Institutions (IFIs). In ensuring its continued effectiveness as well as in enhancing the governance robustness, any existing gaps must be tackled and resolved proficiently. Among the gaps recorded in the previous literature directed to various areas such as the commitment of Shariah Governance body or management team towards its governance, Shariah Committee (SC) portfolio, competency, regulatory framework and so forth. This research paper explores the practical adoption which could be applied to the theoretical analysis and viable recommendation for further enhancement of the SGF by all management teams

\footnotetext{
${ }^{1} \mathrm{PhD}$ Researcher of International Islamic University Malaysia (IIUM) Institute of Islamic Banking and Finance (IIBF), Malaysia. Email: fizafadzli03@gmail.com (corresponding author)

2 Associate Professor, Department of Finance, Kulliyyah of Economics \& Management Sciences, International Islamic University Malaysia (IIUM). Email: irwani@iium.edu.my
} 
in the IFIs. In complementing this study, a set of questionnaires is distributed to some selected group of staff in a Takaful Operator (TO) in Malaysia to gauge their understanding of the subject matter.

\section{Literature Review}

\subsection{Management in the Shariah Governance Framework}

There are various definitions of management recorded in previous studies. Howell \& Costley (2001), explains that management is all about "doing things right" in clarifying its distinction from the meaning of leadership. Through their analysis of previous writings, both simplify that leadership as "doing the right things". Rooted from the verb 'manage', in a nutshell, it refers to an act of handling matters or things. In expanding the word to 'manager', this could refer to a person who handles matters and things as assigned. Nevertheless, it is noted in the modern era, the term leadership and management are used interchangeably as it refers to the same parties who perform the task, which is leading and managing. (Howell \& Costley, 2001). Differently, Beck (1999) stated that managers hold the management designation due to a formal appointment by the company. Leaders and leadership, however, might be both official and unofficial as well as it could be implemented by anyone in the organization. Leaders could exercise their leadership function within a certain area such as in a small group, department or even for the organization as a whole.

Management, as defined by Olum (2004) is "the art, or science, of achieving goals through people. Essentially, management entails the acquisition of managerial competence and effectiveness in the following key areas: problem-solving, administration, human resource management, and organizational leadership". Henri Fayol $^{3}$, in his strategic analysis of management related studies coined the statement which mentioned; "the responsibility of general management is to conduct the enterprise toward its objective by making optimum use of available resources. It is the executive authority, who draws up the plan of action, selects personnel, determines performance, ensures and controls the execution of all activities." (Wren \& Bodleian, 1994).

Based on Level \& Galle (1988), a manager is described as one who works through and with people to accomplish organizational objectives. The ability to work with people depends heavily on the communication abilities. Beck (1999) defines a manager as one who works with and through others to meet the objective of an organization. All management comprises five (5) functions; namely; planning, organizing, directing, controlling and motivating. (Beck, 1999). Adopted from Mintzberg's seminal study, he had categorized the management and their roles into three (3) basic roles. They are known as Interpersonal Roles, Informational Roles and Decisional Roles (O'Rourke, 2004). Kurke \& Aldrich (1983) replicated the study done by Mintzberg on the managerial roles and found that fortifying the picture of managers as working in a work setting described by discontinuity, curtness, focus on live media and

\footnotetext{
${ }^{3}$ Henri Fayol is a well-known figure in classical management studies.
} 
reliance on others for initiating contacts. This affirms that the Mintzberg's work was mostly accurate. Apparently, applicable to any area, management is shaped to execute the processes of planning, organizing, commanding, coordinating activities and controlling performance. Based on Fayol's classical works, these five (5) elements constitute to the process which is known as "the management process". (Wren \& Bodleian, 1994). It is undeniable that the management plays a vital role in any organization. Failure or success, it reflects the management in all ways. A study by Proctor \& Doukakis (2003) deliberated that bad internal interaction by management could lead to negative feelings among staffs. Staff demands for a structured administration with directive vision and mission of management team.

Back to a case in point at hand, SGF emphasizes the work of management in delivering their level best for any IFI that appoints them. The significant roles and functions of management are stipulated under the Section 2 of the SGF. This Section 2 lays out the level of responsibility and obligation expected of the Board, Shariah Committee (SC) and management of an IFI. This interdependency has proven their important accountability in ensuring the compliance with Shariah is observed all the times. Three (3) key relationships highlighted below to clarify the fact that management in Malaysian IFIs is interdependent in particular to the Board, SC and Shariah department or division. The management is also responsible for ensuring the smooth running of the organization through other relationships, i.e.: with Risk and Audit Committee. (See Figure 1)

Figure 1: Shariah Governance Framework of Malaysia

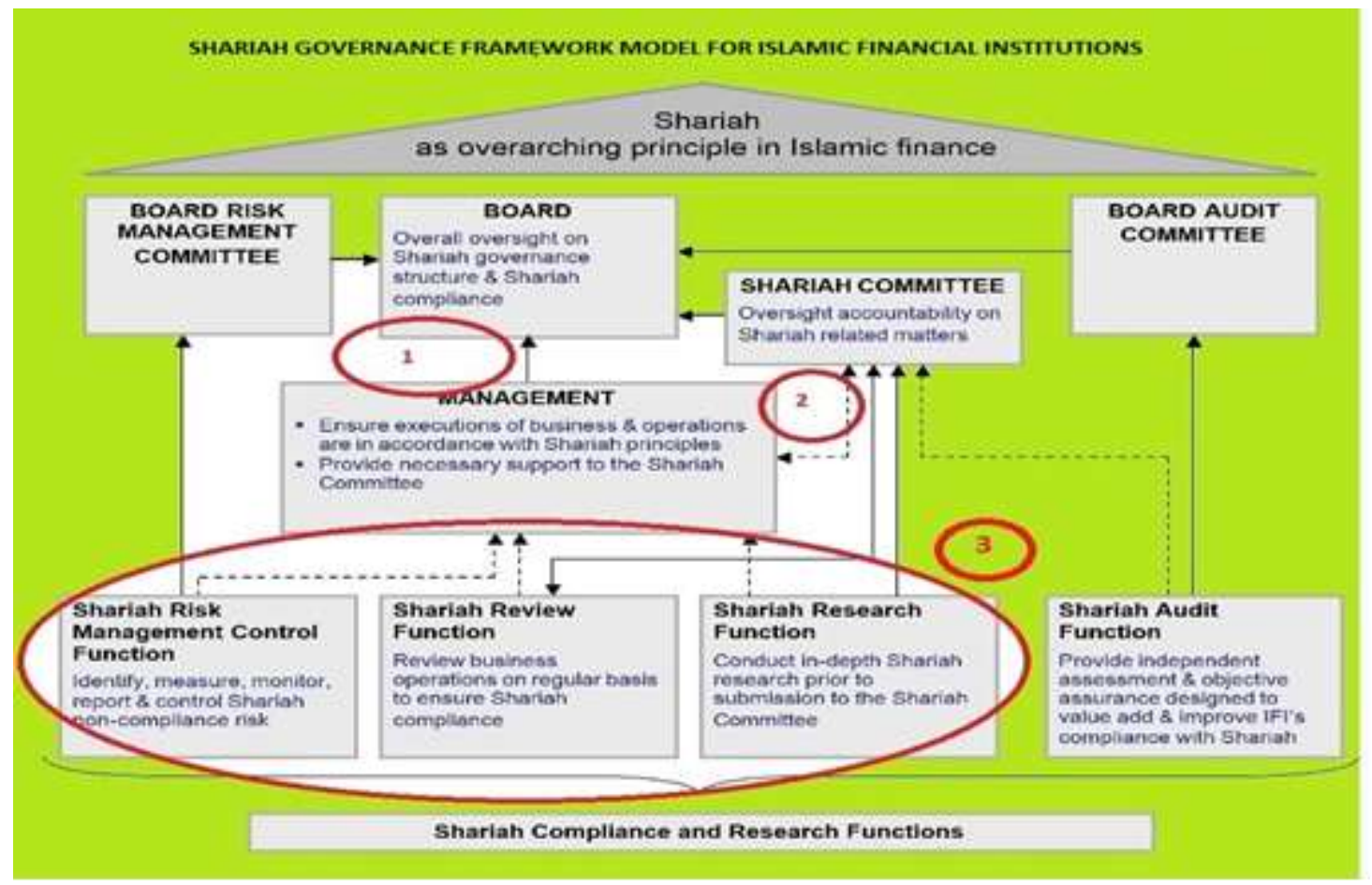

Source: Central Bank of Malaysia (Bank Negara Malaysia) 
In a nutshell, under the ambit of SGF, the management acts as a key organ in helping IFI in achieving as well as maintaining its success in the industry. As mentioned above, the roles of management pronounced in the framework are summarized as follows:

i. Being responsible for observing and implementing Shariah resolutions and regulations made by the Shariah Advisory Council (SAC) of BNM and Shariah Committee (SC) respectively.

ii. Being transparent by providing exact information to the $\mathrm{SC}$ in allowing them to deliver their obligations accordingly

iii. Providing sufficient staff who can support the SGF based on the size of IFI including other relevant facilities such as training, research materials and so forth.

iv. Being responsible for affording training and learning programs to internal stakeholders such as the Board, SC and the relevant staff particularly in Shariah and finance stuff.

v. Being responsible for crafting and inculcate a holistic culture of Shariah compliance within the IFIs. The holistic culture of Shariah compliance refers to end-end observation and application of Shariah precepts and requirements in all business and activities of IFIs. This responsibility requires management to continuously remind all relevant staff on Shariah requirements in every business which is carried out by IFIs as well as the impacts of being noncompliant.

vi. Being responsible for notifying the BNM and SC on any potential and actual Shariah non-compliance events or activities and ensuring the correct rectification measures can be taken into action immediately.

Guided by the roles stipulated in the SGF, management must realize their accountability to ensure Shariah practices are applied in all operations run by the organization. Shariah practice does not focus on product and business only; it needs to be fully embedded holistically.

At this juncture, analyzing the current state of Shariah governance practice is crucially important. Numerous studies had focused on the gaps and challenges faced by IFIs in maintaining the overall Shariah compliance environment. Those challenges have been spread into various angles of governance side. Grassa (2013) emphasized on the Shariah supervisory issue and his exploration on the important gaps with regards to the subject matter. Ismail \& Razak (2014) revealed that on the loophole in relations to Shariah functions within IFI which require for an amicable solution. On another note, Hasan (2014) has conducted his empirical research by discovering all pertinent issues involving Shariah governance practice within the industry. He reiterated on the list of gaps and weaknesses which need to be solved improved in allowing a continuous sound Islamic finance system. One of the most important issues highlighted was involving management within IFIs. 
Hasan (2011) summarized in his findings that there are a lot of deficiencies regarding the implementation of Shariah governance and required for further improvements. The multiple areas concerned are the commitment to Shariah. Based on Hasan (2014), the Shariah scholars in various IFIs in Malaysia, Gulf Cooperation Countries (GCC) and United Kingdom (UK) have affirmed the weaknesses as well as incompetence on the practical side of Shariah governance. Most of the previous studies on SG emphasized on its principles and practical implementation from a macro perspective. These could be found in (Grassa, 2013), Hamza (2013), Nathan \& Pierce (2010) and Hasan (2010). Additionally, none of the previous studies have looked at the other SG's organs besides SC or interchangeably called as Shariah scholars. Studies were done by Hasan (2014), Othman et al., (2013), Malkawi (2013), Farook \& Farooq (2013) specifically focused on issues and challenges faced by Shariah scholars under the ambit of those mentioned above five (5) key issues in SG.

The Shariah scholars have reverted in a survey conducted by Hasan (2014) as follows: "there are gaps between the regulator, IFIs' management and the Shariah board regarding communication and understanding".

\subsection{Theories Related to Management}

As a part of strategies in enhancing the SGF through effective management, it is worth to discover some relevant theories on management. Howell \& Costley, (2006) emphasized the majority of this subject matter expert unanimously agreed that the effectiveness of management is based on condition and supporters' qualities. This further clarifies that certain management style might match and is suitable for one situation; hence, it is not effective for another group of people and environment. Some renowned theories in supporting this deliberation are "The Path-Goal Theory, The Situational Leadership Theory and The Multiple Linkage Model". These contingency theories explain on how management effectiveness is shaped by leadership's design and situation. Even though the models are directed more to leadership, it is mainly linked to management capacity in governing their organization. This section shall discuss on how these theories would be applied in SGF through management key organ.

\subsubsection{The Path-Goal Theory}

This theory is embedded with four (4) management skills such directing, supporting, participating and success oriented. Based on Landrum \& Vjin (2012), the theory is "presupposes leaders, situational characteristics, and followers". The crux of this theory claiming that "leadership behaviour types which include directive, supportive, participative and achievement-oriented leaderships can be exercised in different situations and times by the same person. By applying one of these leadership behaviours, the managers try to affect the concepts of their subordinates, and pave the way for achieving their goals" (Alanazi, Alharthey \& Rasli, 2013). Through this 
technique, the effectiveness of management could be enhanced, and potential loopholes are mitigated accordingly. The focus is to gain the employees' thrust, empowerment, and delight, therefore, they become productive members of the organization. Based on this mould of theory, the direction in the SGF should emphasize on the role of management in spreading the spirit of Shariah throughout the organization. Supported with the functions performed by internal Shariah department, any IFI would be possible invigorate the Islamic culture and ambient in every process and company activities.

\subsubsection{The Situational Leadership Theory}

This model was introduced by Ken Blanchard and Paul Hersey to explain how management effectiveness is achieved through its four (4) conducts. These conducts or behaviours are combined from task and relationship orientation which would also be subject to staff's acceptance of any assigned task to them. (Howell \& Costley, 2006). Based on the model, the management team needs to access their subordinate developmental state to match it with an appropriate leadership style. Apparently, leaders must learn their subordinates' behaviour before deciding to be any of these leadership styles, namely telling, selling, participating or delegating. Yukl (1981) recommended that those with the majority important commitment which developed from those types of styles will be its accentuation ahead pioneers adaptability or versatility. Hersey (1997) defined that "Situational Leadership focuses on the appropriateness or readiness of the follower". As mentioned, all the four quadrants which comprise of task-oriented and relationship-oriented emphasized both subordinates' working efficiency and taking care of their well-being and needs. (Howell \& Costley, 2006). Hersey (1997) summarized this model as follows:

"High-task/low-relationship leader behaviour (S1) is referred to as "telling" because this style is characterized by one-way communication in which the leader defines the roles of followers and tells them what, how, when, and where to do various tasks. High-task/high-relationship leader behaviour (S2) is referred to as "selling" because with this style most of the direction is still provided by the leader. The leader also attempts through two-way communication and socio-emotional support to get the followers psychologically to "buy into" decisions that have to be made. High-relationship/low-task leader behaviour (S3) is called "participating" because with this style the leader and followers now share in decision making through two-way communication and much facilitating behaviour from the leader since followers have the ability and knowledge to do the task. Low-relationship/low-task leader behaviour (S4) is labelled "delegating" because the style involves letting followers "run their own show." The leader delegates since the followers are high in readiness, have the ability, and are both willing and able to take responsibility for directing their own behaviour".

The overview of this theory is shown in Figure 2: 
Figure 2: Situational Leadership

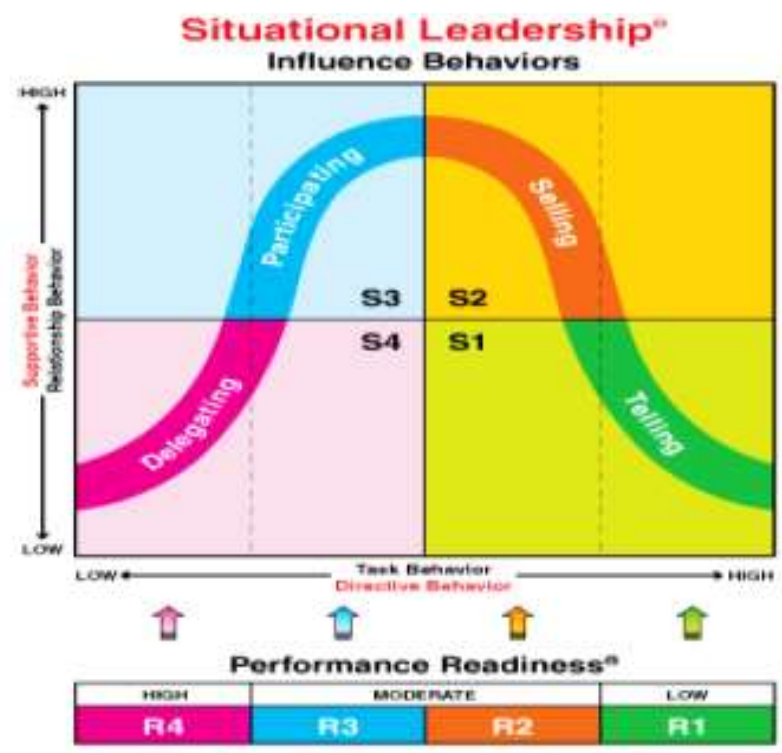

SGF clearly showed the general interdependencies of all key organs which must be interpreted by each of IFI based on its business complexity and organizational size. However, it is the responsibility of the management to ensure the shape of their managing other subordinates is matched. Programmes such as a coffee session with staff, away day, engagement time with lower level staff would benefit IFI in developing its organization within the strategy of this theory. Different from the Board of Directors (BOD) and Shariah Board, the management team is the ones who lead an IFI. Their understanding of the needs of subordinates would ensure the objective of being compliant with Shariah can be easily obtained.

\subsubsection{The Multiple Linkage Model}

Based on Howell (2006), "the multiple-linkage model builds upon earlier models of leadership and group effectiveness. It was developed by Gary Yukl, and proposes that the overall impact of specific leader behaviours on group performance is complex and is composed of four sets of variables. The four variables are: managerial behaviours, intervening variables, criterion variables, and situational variables".

This model presents four general classes of authority conduct that are separated into eleven mid-range practices, which thus include various particular conduct. As indicated by Yukl's (1982) Multiple Linkage Model, a leader's viability in the short run relies on upon his or her aptitude in acting to adjust to any lacks in subordinate inspiration, part clarity, task abilities, assets expected to do the assignment, association and coordination of subordinate exercises, and gathering cohesiveness and cooperate on. The circumstances figure out which of these mediating variables are essential, which needed changes and what potential remedial activities are accessible to the pioneer. 
A leader or manager would not be ideally compelling if he or she neglects to perceive insufficiencies in the mediating variables, if the inadequacies are perceived however the leader neglects to act, or if the leader demonstrates yet does not have the essential expertise to finish the sought changes. The model does not infer that only specific example of leader conduct is ideal in a given circumstance (Yukl, 1982). "In the short term, the job of the leader is to correct deficiencies arising in the intervening variables. In the long term, the job of the leader is to improve situational factors". (Howell, 2006).

The comprehensive leadership variables which developed in this theory is suitable for application by any management team including IFI. Two ways dynamic interactions between management and subordinates would allow the top level of IFI to learn about the concerns of the lower level. Based on Islamic Financial Services Board (IFSB) through its IFSB-10 which was issued in December 2009, it is mentioned that Shariah governance system lies on the full compliance by the Shariah Board and other stakeholders such as management, shareholders, regulators and internal/external clients.

\subsection{Factors Leading to Effective Management}

Management needs their subordinates to ensure any assigned tasks are accomplished and vice versa. Good management is known to be effective. Williams (2009) defined effective management as the capability of getting jobs done as aspired by any organization he or she is attached to.

Effective management which includes managing people and resources is vital in achieving competitive advantage for any organization. From various sources reconsidered, Pfeffer (1995) had summarized thirteen (13) factors which contribute to effective management. In the light of this discussion, only five (5) key factors are selected for analysis and exploration within the ambit of SGF.

\subsubsection{Employment Security}

Based on Pfeffer (1995), "Security of employment signals a long-standing commitment by the organization to its workforce." Employees are the "jewels" for the management team. Without their relevant and continuous support, any organization would collapse. Therefore, subordinates' voices always matter to management. "Employment security is the ultimate form of commitment that companies can make to their workers. Employees can innovate and increase company productivity without fearing the loss of their jobs" (Williams, 2009). According to Abd. Majid \& H. Kassim (2015) the tremendous development of Islamic Finance in Malaysia, some checks, and reviews of this area are required to be conducted as it has also attracted the attention of various ventures. With the rapid growth of Islamic finance industry today, employment security is worth to be emphasized by the Board and other stakeholders. 
Initially, the management, through their role in ensuring overall Shariah compliance would keep the organization remains sound and competitive. It is clearly mentioned in the SGF as follows:

"2.17 In the event the management becomes aware that certain operations are found to be carrying out business(es) which is (are) not in compliance with Shariah, or against the advice of its Shariah Committee or the rulings of the SAC $C^{4}$ the management shall:

(i) immediately notify the board and Shariah Committee as well as the Bank of the fact;

(ii) immediately cease to take on any new business related to the Shariah noncompliant business; and

(iii) within thirty (30) days of becoming aware of such non-compliance or such further period as may be permitted by the Bank, furnish a plan to rectify the state of non-compliance with the Shariah, to be duly approved by the board and endorsed by the Shariah Committee".

This kind of preventive measure is emphasized by BNM. It is proven with the robustness of internal governance played by all key organs within any IFI. Each serves as a security comfort among the employees to stay longer in the organization.

\subsubsection{Selectivity in Recruiting}

Hiring employees for Islamic finance requires for additional values compared to conventional organizations. It is reiterated by Pfeffer (1995) that "security in employment and reliance on the workforce for competitive success mean that one must be careful to choose the right people, in the right way". He added that based on research, it was proven that productive employees are those who were selected to do their matched job. SGF is concerned about the competence issue which must be observed by all Malaysian IFIs.

This competency applies to all key organs as well as the employees who should be qualified on their relevant portfolios. This matter, therefore, reflects the management in their capacity and wisdom to choose competent, talented and skillful employees to work with them. IFSB-10 also spells out the competency related point under Part II (Principle 2.1: The IIFS ${ }^{5}$ shall ensure that any person mandated with overseeing the Shariah Governance System fulfills acceptable fit and proper criteria). The emphasis is deliberated on the requirement of being "fit and proper" characteristics which need to be possessed by all the key organs of IFI. The same goes

\footnotetext{
${ }^{4}$ SAC means Shariah Advisory Council. In Malaysia, SAC is the term used for Shariah advisory body under the Central Bank of Malaysia or Bank Negara Malaysia (BNM)

5 IIFS refers to Institutions offering Islamic financial services (which, for the purpose of this document only, shall include Islamic windows operation, Islamic insurance/Takaful institutions and Islamic mutual funds, as well as fund management companies)
} 
for other employees who are attached to internal Shariah department. Their qualification such as in Shariah and Figh / Usul Al-Fiqh is critically important to ensure the effectiveness of tasks accomplishment and minimizing any possible Shariah noncompliance risk to the IFI.

\subsubsection{High Wages}

Outstanding organizations usually can offer a luxurious package of salary and perks to their employees. Pfeffer (1995) simply stated "high wages tend to attract more applicants, permitting the organization to be more selective in finding people who are going to be trainable and who will be committed to the organization'. Henri Fayol explained that wages are a part of remuneration which includes other elements such as bonus and non-financial incentives. According to him, any organization should reward employees appropriately and could not be too excessive. (Wren \& Bedeian, 1994) Compared to conventional financial institutions, IFIs require for qualified and skillful talents to join the organization. In the SGF, it is summarized by NuHtay \& Salman (2013) that "any person bearing responsibilities outlined in the Shariah governance framework for an IFI shall possess the necessary competency and continuously enhance their knowledge and understanding on the Shariah as well as keep abreast of the latest developments in Islamic finance".

IFSB-10 is silent on any proposed practices for IFI in determining the wages and benefit for the management and other organs. The emphasis is more on virtues and characters which are very subjective in nature. This is, however, very in line with Shariah spirit which must be inculcated in every IFI which operates based on Islamic injunctions. Moral hazards and prior bad experiences are taken into account while selecting any top management to helm any IFI in Malaysia.

\subsubsection{Information Sharing}

Pfeffer (1995) mentioned "If people are to be a source of competitive advantage, clearly they must have the information necessary to do what is required to be successful". Effective management requires for relevant information shared and cascaded down to the subordinates. According to Williams (2009), employees need to be supplied with information on outlays, finances, production, development times, and approaches that were previously known only by company managers in order to allow them to make verdicts that are good for the long-run health and success of the company.

SGF deliberated this element through management's accountability in providing information to the SC appropriately. At the same time, management is responsible for ensuring the overall Shariah compliance culture is spread throughout the organization. This, nevertheless, needs to further details regarding organizational movement, strength, and stability, particularly to subordinates to ensure transparency. 


\subsubsection{Training and Skill Development}

An effective management never forgets to invest in training and development skill. William (2009) has given an example, "like a high-tech company that spends millions of dollars to upgrade computers or research and development labs, a company whose competitive advantage is based on its people must invest in the training and skill development of its people". The consequence of appropriate training could turn into positive outcome only if the trained employees are then permitted to employ their skills accordingly (Pfeffer, 1995).

Porter et al., (2008) stated that training enables learning to head for job performance and can transform knowledge, expertise, and attitudes. The objective of training and development is to enable staff to gain the knowledge, expertise, abilities, and attitudes necessary to allow them to improve their working achievement. Training emphasizes on three (3) main things, namely; implementation, improvement, and innovation. Any organization requires for training and developments due to some of these reasons: (Porter, Simmonds \& Bingham, 2008).

- Accomplishing duly achieved job performance

- Increase of employee hidden capabilities

- Improved spirits

- Improved value

- Greater customer satisfaction

- Enhanced resources utilization

SGF has stipulated that management is accountable to allocate time and expenses for constant learning courses for all other governance organs and relevant staff. "Any person bearing responsibilities outlined in the Shariah governance framework for an IFI shall possess the necessary competency and continuously enhance their knowledge and understanding on the Shariah as well as keep abreast of the latest developments in Islamic finance" (NuHtay \& Salman, 2013).

\section{Methodology}

\subsection{Research Design}

Survey research is one of the most important areas of measurement in applied social research. The broad area of survey research encompasses any measurement procedures that involve asking questions of respondents. A questionnaire comprises of some questions printed or typed in a definite order on a form or set of forms. (Kothari, 2009).

The questions formulated for this survey is based on three (3) themes which are relevant to this study. The formulation of this survey basically consists of the components as deliberated by Kothari (2009) namely general forms, question sequence and question development and wordings of choice. Theme one (1) of this survey is the evaluation of TO's management and communication. It is followed by 
theme two (2) which is to examine the role of management within TO. Last but not least, the final theme deals with the identification factors which lead to effective management.

In formulating the components for evaluation of TO's management and communication as well as their roles as shown in Table 1 and Table 2 respectively, this research is guided by Guiding Principles Shariah Governance Systems for Institutions Offering Islamic Financial Services (IFSB-10) which issued by Islamic Financial Services Board (IFSB). The measurement was basically meant for Shariah Board but for the course of achieving this research objective, the unit of analysis was changed to Management. For the factors leading towards effective management, the list was gathered from Pfeffer (1995). This profoundly was adopted to suit the TO's environment and other IFIs. See Table 3.

\subsection{Population and Sample}

As this survey is conducted to complement this research, it is noted that the data is crucially beneficial for researchers for future analysis and studies. There were 50 survey questionnaires were distributed to various level of staff in a Takaful Operator (TO) which is based in Malaysia. Regardless their position and department attached to, this survey is expected to be irrelevant to certain staff. This growing TO just reach its ten years anniversary and it is head quartered in the city center of Kuala Lumpur. Out of 50 surveys distributed, the researcher managed to receive back 39 which was duly completed by respondents. There are two (2) principal reasons why people do not return questionnaires based on Baruch (1999). It is due to they simply did not receive them and secondly is because of they do not want to respond. The first reason was not possible for this case as the researcher had personally handed over the physical questionnaire surveys to randomly selected respondents. The second might appeal as the questionnaires are on the governance-related and might be caused by extensive questionnaires distributed to them before, particularly to those in managerial levels. (Baruch, 1999).

It might be beneficial to discover possible ways of getting respondents to respond. VanGeest, Johnson, Welch (2007) highlighted on approaches which might be workable for favorable response in physician survey. Those strategies are based on monetary reinforcement and "design-based approaches (e.g., personalized mailings, design-friendly questionnaires, sponsorship, etc.)".It was proven that incentive-based method effective in encouraging the respective respondents to participate in the questionnaires survey conducted.

\subsection{Data Analysis}

The returned surveys were completed by respondents accordingly. The respondents were the majority of female staff by percentage of $71.8 \%$. The awareness level of TO's organizational structure and relevant applicable laws are good and 
encouraging. Basically, most of the respondents have chosen to agree the TO's management has demonstrated effective organizational accountability, communicating effectively with other organs of Shariah governance which reflected $71.8 \%$. It was agreed by $59.9 \%$ of respondents that the management is done a proper identification and evaluation its TO's exposure to Non-compliance to Shariah risk which is seen to be crucial for IFI in Malaysia.

The details of this evaluation, please refer to Table 1.

Table 1: Evaluation of TO's Management and Communication

\begin{tabular}{|c|c|c|c|c|c|c|}
\hline & $\begin{array}{l}\text { Strongly } \\
\text { disagree }\end{array}$ & Disagree & Neutral & Agree & $\begin{array}{l}\text { Strongly } \\
\text { agree }\end{array}$ & Total \\
\hline $\begin{array}{l}\text { The management has demonstrated } \\
\text { effective organizational accountability. }\end{array}$ & 1 & 1 & 8 & 28 & 1 & 39 \\
\hline$\%$ & 2.6 & 2.6 & 20.5 & 71.8 & 2.6 & 100 \\
\hline $\begin{array}{l}\text { The management has communicated } \\
\text { effectively with other organs of } \\
\text { governance, including the BOD, SC, } \\
\text { Shariah Department/Unit/Division and } \\
\text { auditors. }\end{array}$ & 2 & 2 & 7 & 28 & 0 & 39 \\
\hline$\%$ & 5.1 & 5.1 & 17.9 & 71.8 & 0 & 100 \\
\hline $\begin{array}{l}\text { The management has properly identified } \\
\text { and evaluated the organization's exposure } \\
\text { to Shariah non-compliance risk and } \\
\text { reputational risk, and effectively } \\
\text { communicate that risk information to } \\
\text { appropriate bodies in the TO. }\end{array}$ & 1 & 2 & 10 & 23 & 3 & 39 \\
\hline$\%$ & 2.6 & 5.1 & 25.6 & 59.9 & 7.7 & 100 \\
\hline $\begin{array}{l}\text { The management promotes Islamic ethics } \\
\text { and values within the TO. }\end{array}$ & 1 & 3 & 10 & 20 & 5 & 39 \\
\hline$\%$ & 2.6 & 7.7 & 25.6 & 51.3 & 12.8 & 100 \\
\hline $\begin{array}{l}\text { The management promotes continuous } \\
\text { improvement of the TO's Shariah control } \\
\text { processes. }\end{array}$ & 1 & 13 & 20 & 5 & 0 & 39 \\
\hline$\%$ & 2.6 & 33.3 & 51.3 & 12.8 & 0 & 100 \\
\hline
\end{tabular}

In evaluating the role of TO's management, some list of roles as prescribed in the SGF has been adopted to ensure the targeting objective is achieved. According to the survey result, it could be concluded that most of the respondents agreed that the management played their roles as stipulated by the regulatory authority as well as internal organizational arrangement. Most of the respondents were of the view that TO's management plays a critical role in developing takaful products and campaigns. This is represented by $69.2 \%$ of agreed respondents. The overall result under this theme is shown in Table 2. 
Table 2: Evaluation the Role of TO's Management

\begin{tabular}{|c|c|c|c|c|c|c|}
\hline & $\begin{array}{l}\text { Strongly } \\
\text { disagree }\end{array}$ & Disagree & Neutral & Agree & $\begin{array}{c}\text { Strongly } \\
\text { agree }\end{array}$ & $\begin{array}{l}\text { Row } \\
\text { Total }\end{array}$ \\
\hline $\begin{array}{l}\text { The management of aware on the Shariah } \\
\text { pronouncements made by the SC }\end{array}$ & 0 & 3 & 7 & 26 & 3 & 39 \\
\hline$\%$ & 0 & \begin{tabular}{|l|l|}
7.7 \\
\end{tabular} & 17.9 & 66.7 & \begin{tabular}{|l|l|}
7.7 \\
\end{tabular} & 100 \\
\hline $\begin{array}{l}\text { The management obtains the SC approval } \\
\text { for TO's documentations about the } \\
\text { products and services, as well as the } \\
\text { internal policies, manuals, marketing } \\
\text { collaterals, etc. }\end{array}$ & 0 & 1 & 5 & 21 & 12 & 39 \\
\hline$\%$ & 0 & 2.6 & 12.8 & 53.8 & \begin{tabular}{|l}
30.8 \\
\end{tabular} & 100 \\
\hline $\begin{array}{l}\text { The management oversees the } \\
\text { computation and payment of TO's zakat or } \\
\text { any charitable funds. }\end{array}$ & 0 & 1 & 7 & 25 & 6 & 39 \\
\hline$\%$ & 0 & 2.6 & 17.9 & 64.1 & 15.4 & 100 \\
\hline $\begin{array}{l}\text { The management involves intensively in } \\
\text { examining any inquiries referred to its TO }\end{array}$ & 0 & 0 & 14 & 23 & 2 & 39 \\
\hline$\%$ & 0 & 0 & 35.9 & 59.0 & 5.1 & 100 \\
\hline $\begin{array}{l}\text { The management plays critical role in } \\
\text { developing takaful products and } \\
\text { campaigns }\end{array}$ & 0 & 0 & 2 & 27 & 10 & 39 \\
\hline$\%$ & 0 & 0 & 5.1 & 69.2 & 25.6 & 100 \\
\hline $\begin{array}{l}\text { The management acts as the highest } \\
\text { guardian of Shariah issues/Shariah } \\
\text { compliance matters involving its TO after } \\
\text { the SC and the Board }\end{array}$ & 0 & 2 & 6 & 23 & 8 & 39 \\
\hline$\%$ & 0 & 5.1 & 15.4 & 59.0 & 20.5 & 100 \\
\hline $\begin{array}{l}\text { The management plays a role in bridging } \\
\text { the SC and the Board }\end{array}$ & 0 & 1 & 6 & 26 & 6 & 39 \\
\hline$\%$ & 0 & 2.6 & 15.4 & 66.7 & \begin{tabular}{|l|}
15.4 \\
\end{tabular} & 100 \\
\hline $\begin{array}{l}\text { The management involves in resolving any } \\
\text { relevant Shariah audit issues/findings } \\
\text { raised by Shariah Auditors }\end{array}$ & 0 & 1 & 6 & 24 & 8 & 39 \\
\hline$\%$ & 0 & 2.6 & 15.4 & 61.5 & 20.5 & 100 \\
\hline $\begin{array}{l}\text { The management develops and adopts a } \\
\text { Shariah compliance culture within its TO. }\end{array}$ & 0 & 3 & 9 & 23 & 4 & 39 \\
\hline$\%$ & 0 & 7.7 & 23.1 & 59.0 & 10.3 & 100 \\
\hline $\begin{array}{l}\text { The management works closely with its } \\
\text { internal Shariah Department }\end{array}$ & 0 & 1 & 9 & 26 & 3 & 39 \\
\hline$\%$ & 0 & 2.6 & 23.1 & 66.7 & \begin{tabular}{|l|}
7.7 \\
\end{tabular} & 100 \\
\hline $\begin{array}{l}\text { The management ensure all policies, } \\
\text { manuals, and pronouncements developed } \\
\text { by Shariah Department being } \\
\text { communicated to all their immediate } \\
\text { subordinates }\end{array}$ & 0 & 5 & 13 & 18 & 3 & 39 \\
\hline$\%$ & 0 & 12.8 & 33.3 & 46.2 & \begin{tabular}{|l|l} 
& 7.7
\end{tabular} & 100 \\
\hline
\end{tabular}


Last but not least, in the third Table 3, factors leading to effective management have been analyzed. Based on the response gathered, respondents are of the view that the most important factors for this matter are internal \& external communication as well as integrated of both Shariah and corporate governance. Both of these factors were represented by $28.2 \%$ of the response. It is quite interesting to note that $30.8 \%$ respondents had opined that the employment security is least important for their institution.

Table 3: Factors Leading Towards Effective Management

\begin{tabular}{|l|c|c|c|c|c|c|}
\hline & $\begin{array}{c}\text { Most } \\
\text { Important }\end{array}$ & Important & Neutral & $\begin{array}{c}\text { Less } \\
\text { Important }\end{array}$ & $\begin{array}{c}\text { Least } \\
\text { Important }\end{array}$ & Total \\
\hline Employment Security & 5 & 5 & 9 & 8 & 12 & 39 \\
\hline$\%$ & 12.8 & 12.8 & 23.1 & 20.5 & 30.8 & 100 \\
\hline $\begin{array}{l}\text { Internal and External } \\
\text { Communication }\end{array}$ & 7 & 5 & 11 & 10 & 6 & 39 \\
\hline$\%$ & 17.9 & 12.8 & 28.2 & 25.6 & 15.4 & 100 \\
\hline $\begin{array}{l}\text { Excellent Rapport with } \\
\text { Other Governance Organs }\end{array}$ & 11 & 9 & 7 & 7 & 5 & 39 \\
\hline$\%$ & 28.2 & 23.1 & 17.9 & 17.9 & 12.8 & 100 \\
\hline $\begin{array}{l}\text { Integrated Corporate and } \\
\text { Shariah Governance }\end{array}$ & 11 & 13 & 7 & 4 & 4 & 39 \\
\hline$\%$ & 28.2 & 33.3 & 17.9 & 10.3 & 10.3 & 100 \\
\hline Consumers' Perceptions & 6 & 6 & 5 & 10 & 12 & 39 \\
\hline$\%$ & 15.4 & 15.4 & 12.8 & 25.6 & 30.8 & 100 \\
\hline
\end{tabular}

\section{Conclusion}

Based on our analysis in the previous sections, some significant findings could be summarized as follows:

1) In overall, the management of Malaysian IFIs including TO that is espoused by Shariah principles and precepts is classified as effective. In fact, this matter has been duly acknowledged by their staff accordingly.

2) The management of Malaysian TOs basically adheres to the relevant rules and regulations related to IFIs in ensuring full compliance.

3) The effective and efficient organization needs to be embedded with a strong rapport between top management and another level of subordinates. This synergy simultaneously builds robust governance for organization, especially in Islamic finance area. 
The response and effect of this study are valuable for future research of the similar area. The respondents had responded in a day to five (5) working days. However, this outcome has provided the researchers a positive insight in continuing further exploration of this study for the remaining 10 TOs which are currently operating in Malaysia. Realizing the need to increase the accuracy of the result, triangulation method is worth to consider. The most suitable method is a semistructured interview with TOs' top management or executive committee. 


\section{References}

Abd. Majid, M. S., \& H. Kassim, S. (2015). "Assessing the contribution of Islamic finance to economic growth: Empirical evidence from Malaysia", Journal of Islamic Accounting and Business Research, 6(2), 292-310.

Alanazi, T. R., Alharthey, B. K., \& Rasli, A. (2013). "Overview of path-goal leadership theory", Sains Humanika, 64(2).

Beck, C. E. (1999). Managerial communication: Bridging Theory and Practice. Prentice Hall.

Farook, S., \& Farooq, M. O. (2013). "Shariah Governance, Expertise and Profession: Educational Challenges in Islamic Finance", ISRA International Journal of Islamic Finance, 5(1), 137-160.

Goodson, J. R., McGee, G. W., \& Cashman, J. F. (1989). Situational Leadership Theory A Test of Leadership Prescriptions. Group \& Organization Management, 14(4).

Grassa, R. (2013). "Shariah Supervisory System in Islamic Financial Institutions: New Issues And Challenges: A Comparative Analysis Between Southeast Asia Models And GCC Models", Humanomics, 29(4), 333-348.

Hamza, H. (2013). "Sharia governance in Islamic banks: Effectiveness and Supervision Model", International Journal of Islamic and Middle Eastern Finance and Management, 6(3), 226-237.

Hersey, P. (1997). “Situational Leadership”, In DEAN'S FORUM (Vol. 12, No. 2, p. 5).

Howell, J. P., \& Costley, D. L. (2006). $2^{\text {nd }}$ Edition. Understanding Behaviors for Effective Leadership. Prentice Hall.

Ismail, N. A., \& Razak, S. H. A. (2014). "Shariah Governance Framework Gaps and Issues", Islamic Financial Services Board (IFSB)

Kurke, L. B., \& Aldrich, H. E. (1983). “Note-Mintzberg was Right! A Replication and Extension of the Nature of Managerial Work", Management Science, 29(8), 975-984.

Landrum, N. E., Daily, C. M., \& Vjin, S. (2012). "Corporate accountability: A path-goal perspective", International Journal of Business Insights and Transformation, $4(3)$.

Level, D. A., \& Galle, W. P. (1988). Managerial Communications. Business Publications.

Malaysia International Islamic Financial Centre (MIFC), www.mifc.com. Insights Issued on 27 February 2014.

Malaysia, B. N. (2010). Shariah Governance Framework for Islamic Financial Institutions. Bank Negara Malaysia, Kuala Lumpur. 
Malkawi, B. H. (2013). "Shari'ah Board in the Governance Structure of Islamic Financial Institutions", Am. J. Comp. L., 61, 539.

Nathan Garas, S., \& Pierce, C. (2010). "Shari'a Supervision of Islamic Financial Institutions", Journal of Financial Regulation and Compliance, 18(4), 386-407.

NuHtay, S. N., \& Salman, S. A. (2013). "Comparative Analysis on AAOIFI, IFSB and BNM Shari'ah Governance Guidelines", International Journal of Business and Social Science, 4(15).

Olum, Y. (2004). Modern Management Theories and Practices. Uganda: Makerere University.

O'Rourke, J. S. (2012). Management Communication. Pearson Higher Ed.

Othman, A.A., Hassan R., Omar M. N., Napiah M. D. M., Ariffin M., YUSOFF A., Khatimin N. \& Zaharim A. (2013). "Shariah Governance for Islamic Financial Institutions in Malaysia on the Independency of Shariah Committee and Efficiency of Its Shariah Decisions", Recent Advances in Management, Marketing and Finances.

Pfeffer, J. (1995). Producing Sustainable Competitive Advantage through the Effective Management of People. The Academy of Management Executive, 9(1), 55-69.

Porter, C., Simmonds, D., \& Bingham, C. (2008). Exploring human resource management. McGraw-Hill Higher Education.

Proctor, T., \& Doukakis, I. (2003). "Change Management: The Role of Internal Communication and Employee Development", Corporate Communications: An International Journal, 8(4), 268-277.

Stapledon, G. P., \& Stapledon, G. P. (1997). Institutional Shareholders and Corporate Governance. Oxford University Press.

Williams, C. (2009). Management $5 e$.

Wren, D. A., \& Bedeian, A. G. (1994). "The Evolution of Management Thought".

Yukl, G. (1982). "Managerial Leadership and the Effective Principal”. 